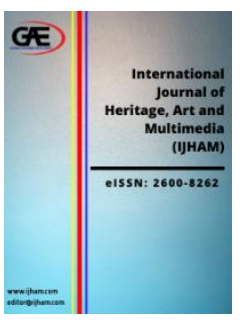

\author{
INTERNATIONAL JOURNAL OF \\ HERITAGE, ART AND MULTIMEDIA \\ (IJHAM) \\ WWW.ijham.com
}

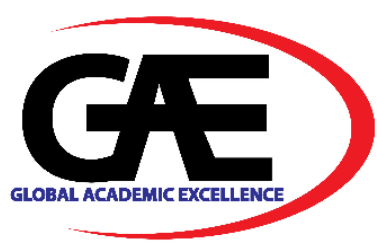

\title{
DIGITAL PRESERVATION OF INTANGIBLE CULTURAL HERITAGE OF JOGET DANCE MOVEMENT USING MOTION CAPTURE TECHNOLOGY
}

\author{
Mohd Firdaus Mohd Herrow $^{1 *}$, Nur Zaidi Azraai ${ }^{2}$ \\ 1 Faculty Communication, Visual Art and Computing, Universiti Selangor (UNISEL), Malaysia \\ Email: firdausherrow@unisel.edu.my \\ 2 School of the Arts, Universiti Sains Malaysia (USM), Malaysia \\ Email: nurzaidi@usm.my \\ Corresponding Author
}

\section{Article Info:}

Article history:

Received date: 18.10 .2021

Revised date: 30.10. 2021

Accepted date: 05.11.2021

Published date: 01.12.2021

\section{To cite this document:}

Mohd Herrow, M. H., \& Azraai, N. Z. (2021). Digital Preservation of Intangible Cultural Heritage of Joget Dance Movement Using Motion Capture Technology. International Journal of Heritage, Art and Multimedia, 4 (15), 01-13.

DOI: $10.35631 /$ IJHAM.415001.

This work is licensed under $\mathrm{CC}$ BY 4.0

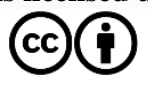

\begin{abstract}
:
Culture and heritage play a major role in the Malay community in terms of linguistic, art craft, traditional ceremonies, music, activities, and performing arts. The Malay folk dances are most frequently described as a way of human expression through movement and traditional elements in storytelling, ritual, feeling manifestation, and conveying the Malay manner and customs as pillars of the Malay ethnic. Joget was created based on Branyo, a famous Portuguese folk dance. It is a hybrid of culture between the West and the East, reflecting heavily the Malay identity and characteristics as the core philosophy of choreography in the routine. The new creation of Malay dance has positively impacted Malay cultural activities. It has also threatened the original dance form which is being forgotten further from the philosophy. This paper was executed using a qualitative descriptive approach. Interviews and literature reviews were used to expose the rich diversity of two-element; joget and motion capture technology. Data verification, data compilation, data comparison, and triangulation are used as a form of data analysis. The results of the study found that the practice of motion capture has been massively used in digitising intangible assets for 3D application in the form of gaming, video interactive, education entertainment, and learning animation as a platform of education and training as a preservation and protection strategy. But motion capture technology has the potential to be explored as a medium in discovering a quality of trajectory micro visualization of joget dance movement and analyse the symbols or signs that can benefit to the young generation that provides a local sense of unity and belongingness that can help develop a new interest in enhancing cultural values and appreciation.
\end{abstract}


Volume 4 Issue 15 (December 2021) PP. 01-13 DOI 10.35631/IJHAM.415001

Keywords:

Intangible Cultural Heritage, Digital Preservation, Malay Folk Dance, Joget, Motion Capture Technology

\section{Introduction}

Culture and heritage have different meanings and functions but both are related, irreplaceable, and important in developing the identity and character in societies. Culture includes the whole ethical actions of spiritual, intellectual, emotional, and factual that describe a unique act of living in a certain society that generates a collection of action (Ahmad, 2006; Amin, Yatim, Deraman \& Baker, 2011; Rohidi, 2015). The culture of arts and literature instils values, creativity, knowledge, tradition, and belief. Culture is presented as human acts on daily activities that form the characteristics of civilization. Culture connects the past, present, and future through information passed from one generation to another based on practices. This can encourage togetherness within the society. This is important so that culture remains relevant and applicable to the need of current society and conforms to fundamental guidelines in terms of religion and civilisation. On the other hand, heritage is shared, learned, and transmitted across generations. It is the knowledge that has been inherited from generation to generation by being passed down through practices and beliefs. Heritage is related to the past that should be preserved as a legacy of ethnic treasure and should be appreciated by the current generation. Heritage is defined as a valuable and ancient legacy not only of each nation but also of humanity as a whole (Manaf \& Ismail, 2010; UNESCO, 2015). This irreplaceable legacy is brought from the past, lived on today, and will be carried to future generations.

According to Md Noor, Khor and Mohamed (2013), heritage is generally defined as the elements from the past. These elements are later carried from one generation to another. The element can be in tangible and intangible forms. Both are considered to be related as well as denote a strong cultural symbol and identities in their context and important to each other. Tangible cultural heritage is divided into two categories; movable and immovable. Movable heritage classification is more focused on artefact and manuscript artwork such as paintings, sculpture, furniture, and wall painting. Meanwhile, immovable heritage comprises human engineering sites like historical buildings, monuments, archaeological sites, and works of the combination of human and natural activity. According to UNESCO (2003), intangible cultural heritage is manifested according to the five domains of oral traditions and expressions, including language, performing arts, social practices, rituals and festive events, knowledge and practices concerning nature and the universe, and traditional craftsmanship. It is also related to human activity as a process of communication and aims at satisfying the spiritual needs within a community.

Performing arts consist of theatre, dance, opera, and the circus, which refer to expression in the form of human artistic gesture as a communication tool. UNESCO defines performing arts as covering a range of vocal, musical instruments, dance, theatre, pantomime, and song verses. Kabanda (2014) highlights that performing arts exhibit direct effects on social progress and indirectly contribute to a nation branding for economic growth, social inclusion, cultural democracy, and cultural behaviour shifts. 


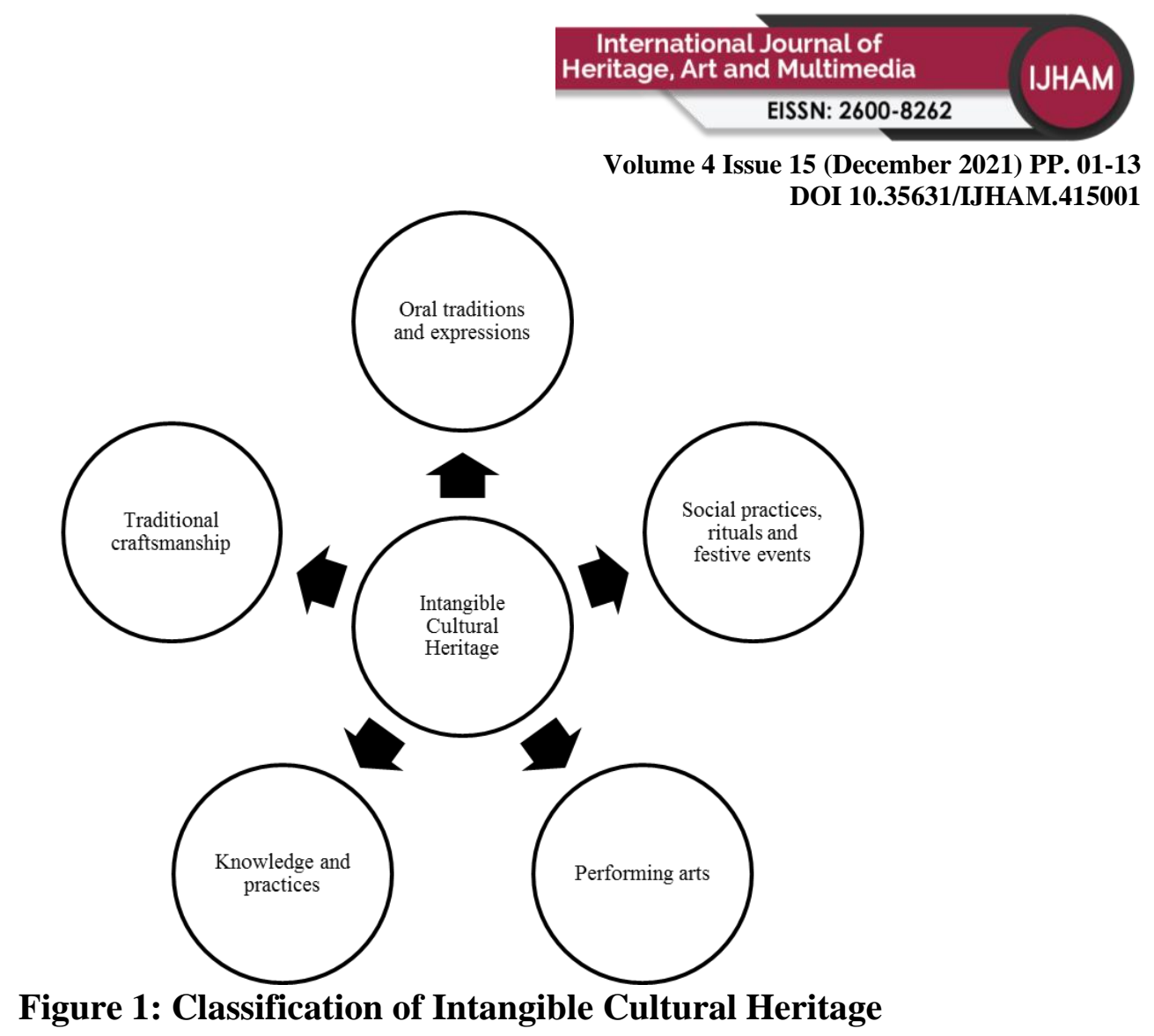

\section{Overview of Malay Folk Dances}

Malay cultural heritage is dear in the Malay society that this is believed to bring pleasantness and excitement to the community. The Malay folk dances have been influenced by several cultural practices and traditional components such as martial arts, storytelling, humour, and teases. The Malay folk dances, through various cultural codes, rely mostly on regions, religions, and beliefs. The dances are mostly performed during certain occasions like weddings, festival celebrations, and even religious ceremonies. According to Soon (2017), the Malay folk dances are unique and diversified and some of them are known as royal court dances. The early Malay folk dances originated in the 14th century in the early Malay Kingdom and were only performed before the noble court; the Sultan and royalty, during special occasions (Idris, Mustaffa, Othman \& Abdullah, 2017).

According to Bannerman (2014) and Koff (2012), dancing is conscious rhythmic body movements in a defined bounded space where it communicates through cultural codes. The dancing choreography is mostly driven by the coordination of the beautiful music and melody alongside the arrangement of good lyrics. The Malay folk dances are built on the foundation of each dance. These elements are divided into four groups which are dance movement, music, instruments, and costumes. 


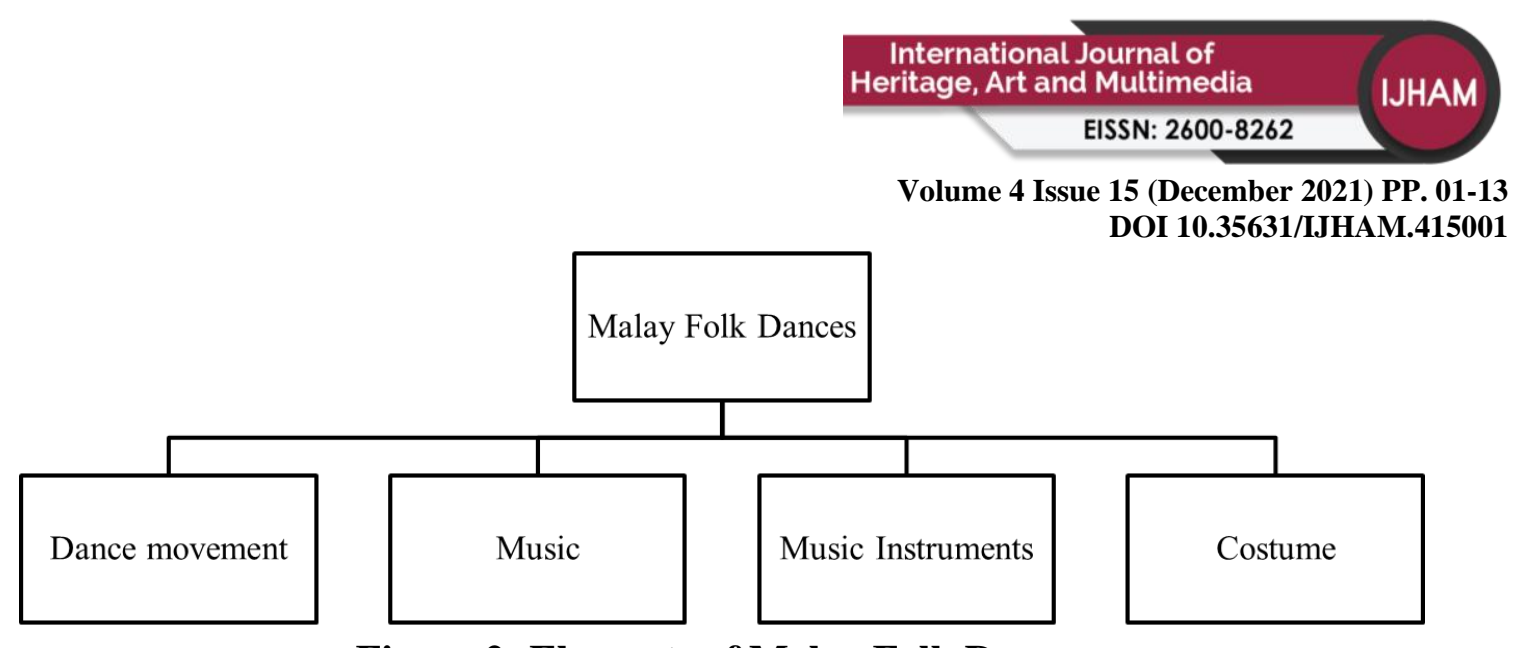

Figure 2: Elements of Malay Folk Dances

There are 10 main categories of Malay folk dances (M. Hum \& Muhammad Dja'far, 2014). They are classified based on their roles which are dances based on agriculture and fishery activities for spiritual purposes, dances that describe palace activities performed by dayang, dances that mimic the flora and fauna to show gratitude to nature, dances based on Islamic religious activities, such as to praise Allah and the Prophet Muhammad, dances related to sports and human immunity to sharp weapons made of iron or metal, dances for entertainment and adopting various cultural elements such as Western, Middle East, and Asia, dances related to wedding, circumcision ceremonies, and berkhatam, especially in the palace, dances related to the Malay theatre like Bangsawan, and dances based on the new creation of choreography adapted from the original dance. These categories are based on cultural roots and their functions as the heart and temperament towards the Malay folk dance in the Malay Archipelago.

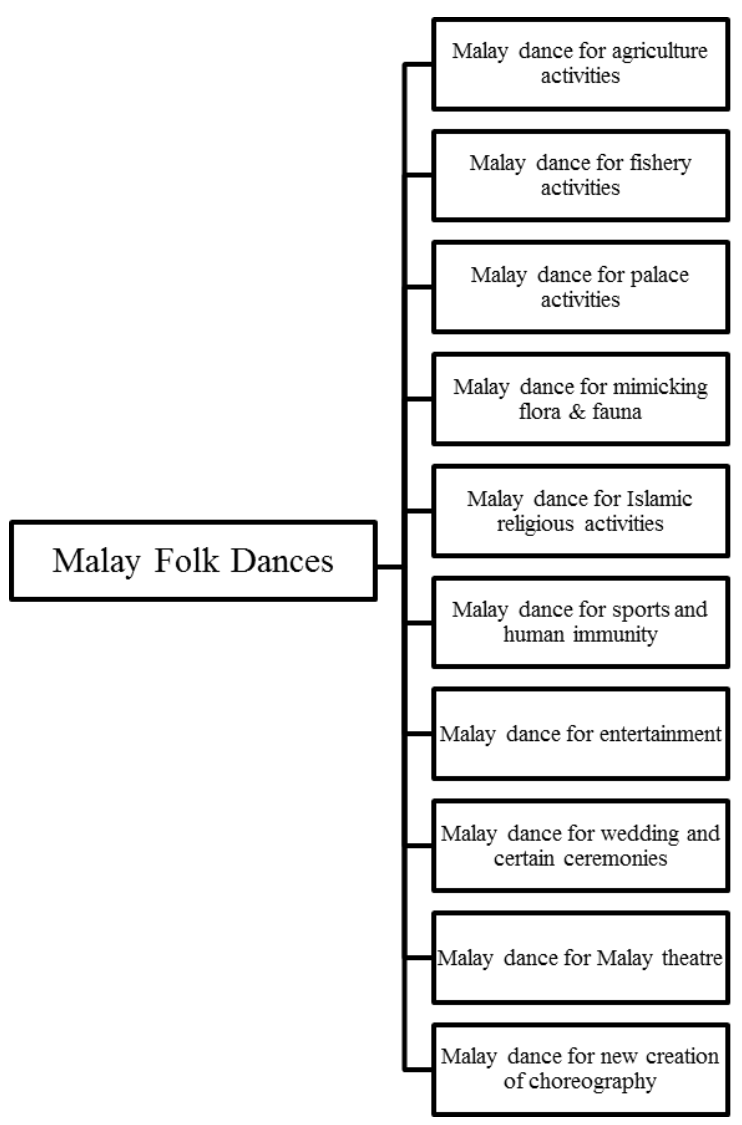

Figure 3: Categories and Roles of the Malay Folk Dances 
Volume 4 Issue 15 (December 2021) PP. 01-13 DOI 10.35631/IJHAM.415001

Each Malay folk dance has its uniqueness, attraction, history, meaning, purpose, and philosophy. However, all types of Malay folk dances have one fundamental element in common.

\section{Joget}

According to Parani (2018), joget is a mixture of culture between the West and the East, between the European and the Asian. The development of joget has started since the colonial era in Southeast Asia. It is a historical shift of cultural development that thrives from an intercultural environment. Joget has become a cultural component of new nations of culture in Indonesia, Singapore, Malaysia, Brunei, and certain regions of Thailand. It has expressively become an adopted local value that emerges as a national heritage that shapes Malay society.

According to Ooi (2011), Muhammad (2014), and Yayasan Warisan Johor (2018), joget was created in Malacca in the 16th century. It was adapted from the Portuguese dance called Branyo. This famous Portuguese folk dance did not originate in Portugal but it was believed to be developed from a dance called Branle, and this dance was famous in the Iberia Peninsula. This dance had a similar dance move to Branyo and later on, it was inspired by the people of Malacca, and the dance developed and created the joget. The dance is usually paired with classic songs from Portuguese like Jingli Nona. Joget dance is very popular among the multiracial community in Malaysia as it is one of the most flexible, unique, and diversified dances that can adapt to the ever-changing dance styles and music. Joget is also known with various names in several places. In Indonesia, it is better known as ronggeng and in Malacca, it is recognised as joget lambak or cak kun cak. It is typically performed in pairs or a group of male and female dancers on special occasions like weddings, official events, and festivals.

Joget can be identified as functional support to sociology institutions to preserve traditions and customs (M. Hum \& Muhammad Dja'far, 2014). It is also a form of art to express cultural and social contact, economic growth, and income activities of the community, aesthetic presentation and commercial value, ritual meaning or story, and other values in the context of Malay civilisation.

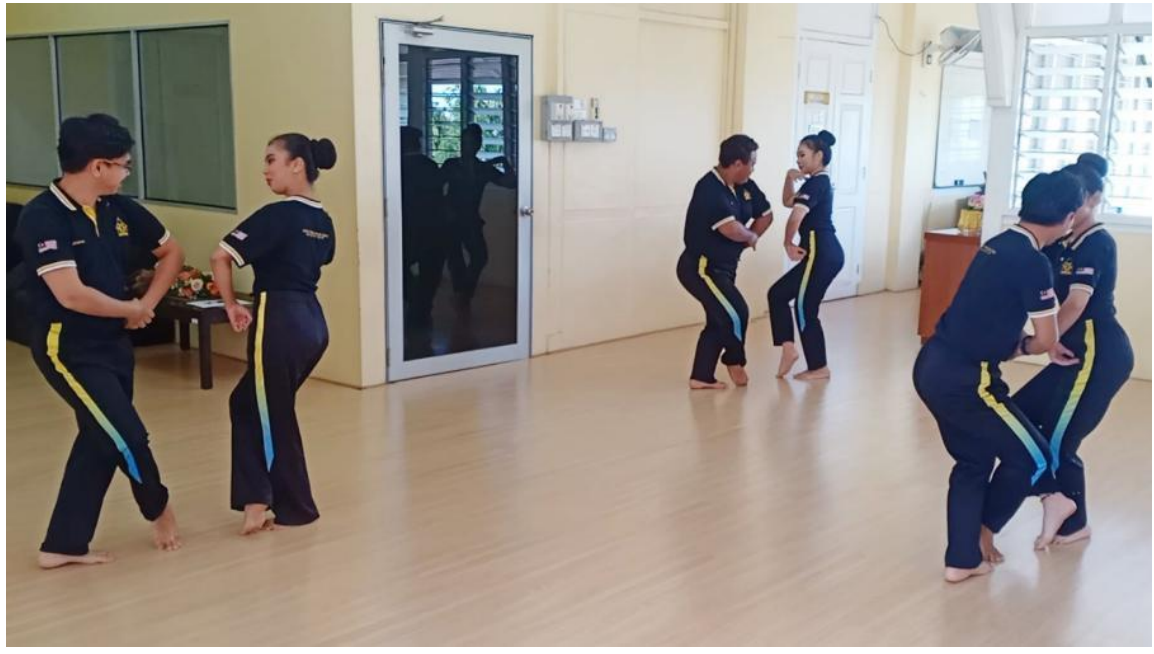

Figure 4: Joget Performed in Group 
Volume 4 Issue 15 (December 2021) PP. 01-13

DOI 10.35631/IJHAM.415001

Joget has developed a unique fast-paced and slow-paced dance style that is well-known throughout Malaysia. It is a combination of both hands and legs movement (Ooi, 2011; Muhammad, 2014; Yayasan Warisan Johor, 2018; Hang, 2020). Legs movements are more crucial compared to hands movements. The tempo and rhythm for a slow-paced dance movement are 2/4 and the fast-paced dance movement is 3/8. It resembles European dances, tarantello and fandango. Joget dance movement frequently symbolizes joy, liveliness, and cheerfulness as portrayed in songs combined with teasing, mocking, and being playful between dancers.

The concept of Malay dance culture is usually expressed and communicated through inner reflections, stories, or values. Some even contain certain denotations and connotations that need to be learned and observed. There are four main terms of the Malay dances; tandak, igal, liuk, and tari (Sheppard, 1972; Gusmail, 2017). The basic movements in joget rely on the leg movements of the dancers according to the rhythm of the music. The majority of the movements in joget focus on and emphasise the leg movements. Leg movements are more aggressive and fast compared to arm or hand movements which are more rigid and fixed.

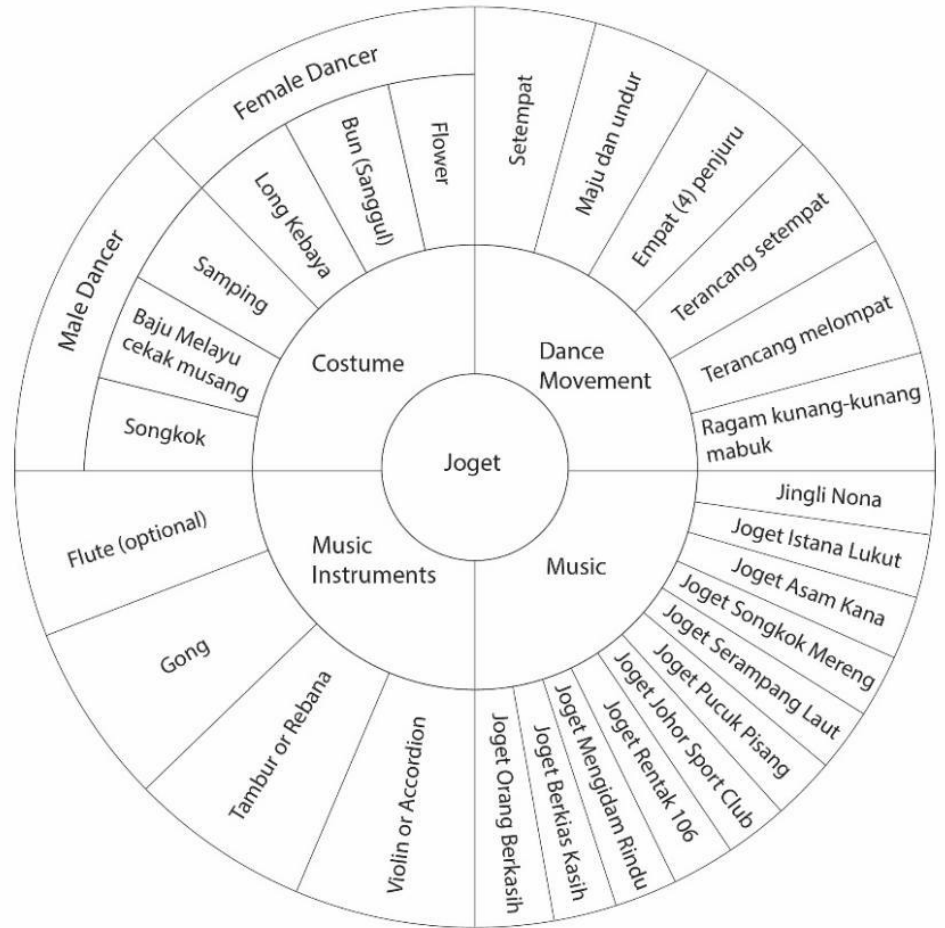

Figure 5: Joget according to Four Elements of Malay Folk Dances

There are three core dance steps in joget that need to be mastered by each dancer. The first step is setempat. This move is considered the first and opening step in every other dance move. Setempat is the dance move that does not involve a large movement of the space. It is just a movement of the legs with little stepping at the same position with the toe touching the floor. Besides that, the wrist and arm movements are like paddling or waving. Then, the basic step patterns emerge to another two structural basic steps known as terancang setempat and ragam kunang-kunang mabuk (also known as ragam gila-gila). These three basic steps of the joget dance movement are developed into a more advanced and complex dance routine. 
Volume 4 Issue 15 (December 2021) PP. 01-13 DOI 10.35631/IJHAM.415001

According to Wan Muhammad Fauzan and Said Husain (2018), the Malay characteristics can be reflected as harmonious, peaceful, well-mannered, and respectful to each other which are among the highlighted personalities. These characteristics have influenced every dance performance in the Malay folk dances. Most dance characteristics project beauty, sophistication, manner, and modesty. The majority of Malay folk dances have their unique dance philosophies and beliefs inherited from generation to generation by maintaining the identities and characteristics. This includes joget, one of the famous, harmonious, diversified, and joyful dances in Malaysia. Based on the four elements in Malay folk dances, joget has been combined and integrated from the Western and Eastern cultures, making this Malay folk dance an exciting and unique dance of all time. This assimilation has shown how this dance has been an important heritage to the community and has been practiced from generation to generation with respect and gratefulness.

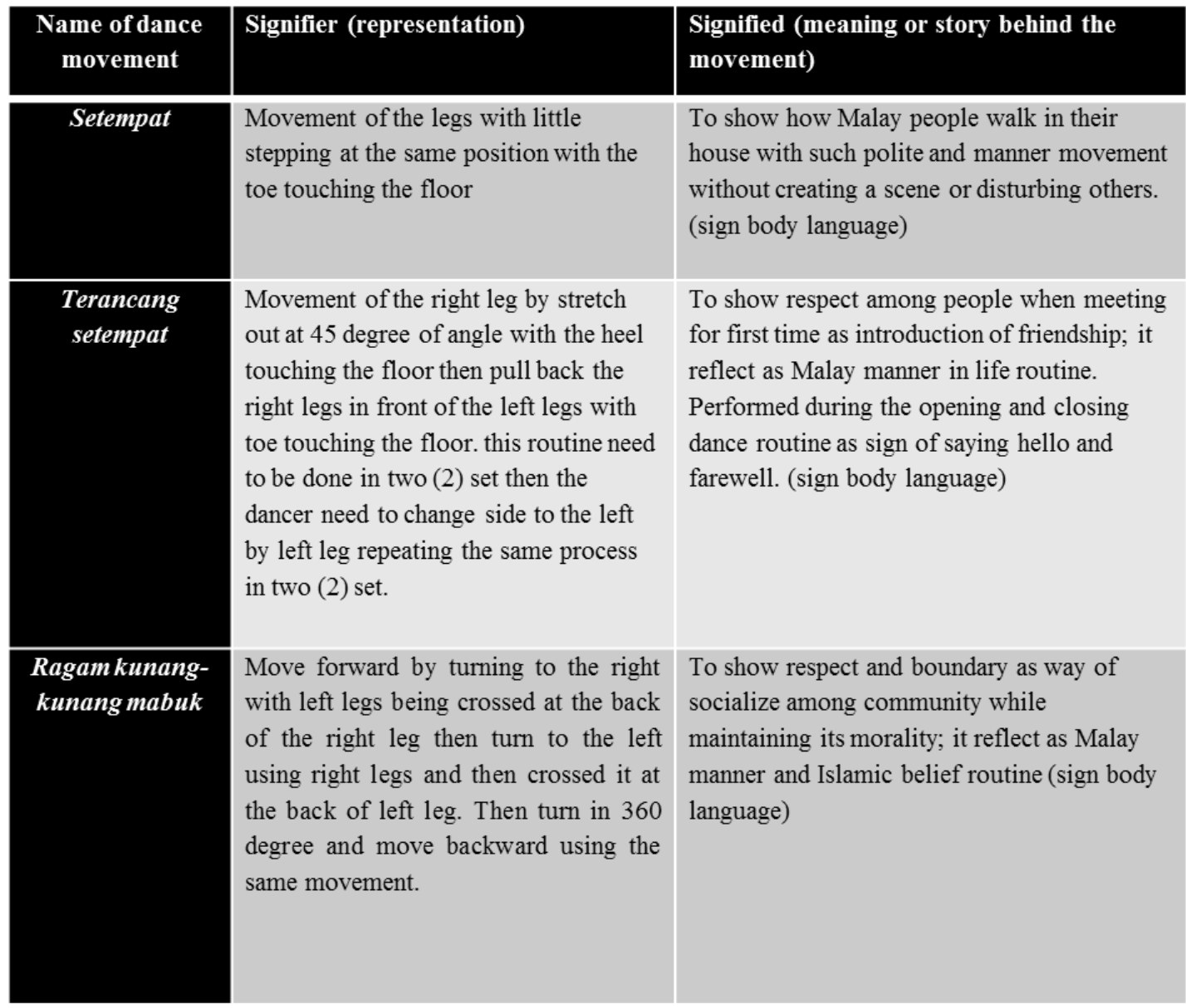

Figure 6: Types of Basic Step Pattern in Joget

Joget is a combination of dance and music, displayed as one of the Malay folk dances with elegance and class and also able to show joy, teasing, and pleasure which can bring unity to the community. Joget has become one of the foundation cultures, especially in the Malay community. Other than that, joget has grown as an activity that encourages people to be creative by developing or creating a new combination of dance steps without losing its original purpose, 
Volume 4 Issue 15 (December 2021) PP. 01-13 DOI 10.35631/IJHAM.415001

identity, and meaning. It also affects the dance and attracts the public in participating as the world has become more challenging and advanced.

\section{Digital Preservation on Malay Folk Dances}

The development in technology has become a key factor in many sectors. This is significant since the combination or collaboration between technology and issue can positively and constructively impact society. It leads to new findings and new knowledge that can provide society with a better world to live in. Heritage preservation is the main issue that has been highlighted by UNESCO and has become a crucial element to maintain the diversity of intellectual treasure. Culture and heritage need to be preserved either in tangible or intangible cultural heritage in the digital platform to create digital heritage. These data are crucial and act as fundamental to learn and spread heritage to the young generation so that it can be maintained and accessed as a unique activity for a certain ethnic.

According to Idris et al. (2017), digital media, tools, and software are the major considerations that influence the quality of digital heritage produced. Each component works in conjunction with the other. It is also important to make the right choice as to what, when, and how these media, tools, and software are utilized to ensure the quality and accuracy of the digital heritage. This emerging field calls for research that addresses issues and strategies of the appropriation and legitimation of digital heritage, its perimeters of preservation, comparative studies of preservation policies, and tools among countries for the younger generation in the future (Musiani \& Schafer, 2017).

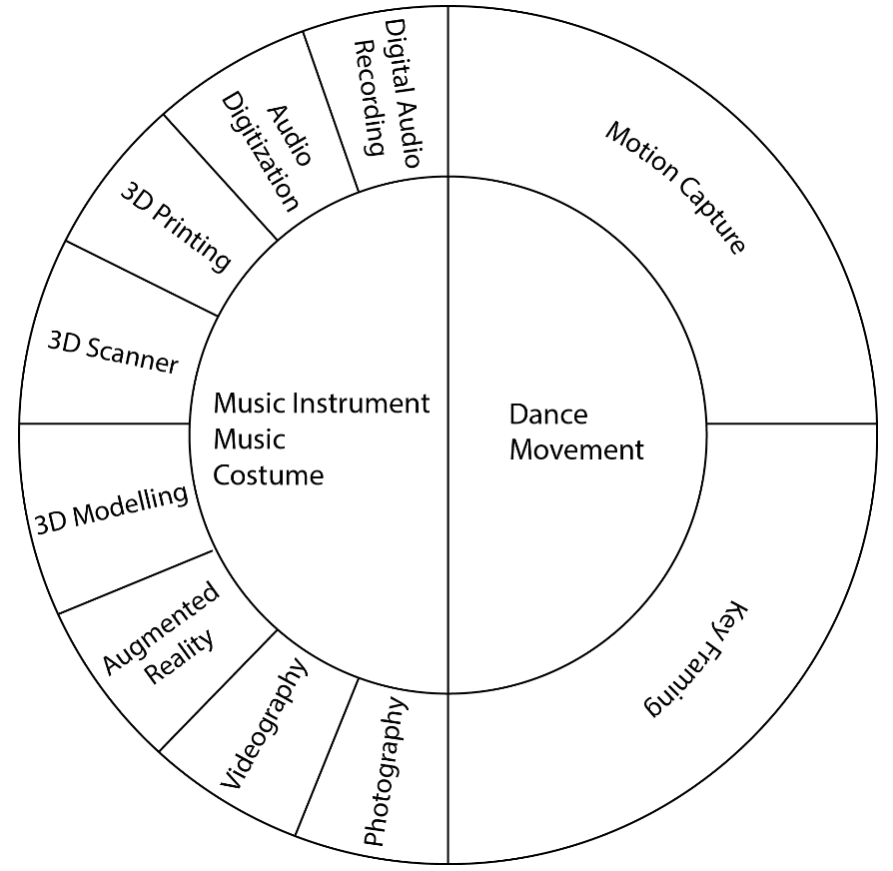

Figure 7: Categorization of Digital Preservation in Malay Folk Dances

Media such as photography, videography, augmented reality, 3D modelling, 3D scanner, 3D printing, audio digitization, and digital audio recording are appropriate tools to be used in preserving the elements of Malay folk dances specifically in music, musical instruments, and costumes. Dance can be taught in many different ways such as text documentation, photos, 
Volume 4 Issue 15 (December 2021) PP. 01-13 DOI 10.35631/IJHAM.415001

videos, and graphical notations (Kico, Grammalidis, Christidis \& Liarokapis, 2018). Nevertheless, all these media have limitations. Most research has been done using media such as photography and videography in recording dance movements. By analysing and accessing the dance movement based on videos or images, it is hard to perceive the actual and structural movement of the dance without any creative and innovative teaching aid as guidance. Lack of accurate information and precise visualisation in dance movements and styles might give delinquent matters for the younger generation to understand the essential meaning and dance movement patterns.

Therefore, when it comes to digitalization and preservation of dance movement, advanced and modern technology is required, such as motion capture technology as the main tool to record, capture, and analyse delicate and subtle movements. It can give detailed information and evidence that can be accessed to expand and enhance the data into identification, documentation, protection, promotion, enhancement, transmission, formal and non-formal education, as well as the recovery of various aspects through the digital platform.

The Motion Capture Technology as a Tool for Digital Preservation of Malay Folk Dances According to Syu, Chen and Tu (2018), digital technology has become an important knowledge and tool for the preservation of cultural assets. A wide range of research uses motion capture technology to gather data and to create new findings such as in sports, medical, military, education, cinematic, and entertainment areas. The gathered information shows an accurate and precise representation of movement qualities. There are tremendous volumes in research using motion capture technology in the area of performing arts, especially to capture movements in dances and theatrical and martial to persevere, document, archive, and learn the materials.

Motion capture has a huge advantage to capture the motion and expression of the subject (Stavrakis, Aristidou, Savva, Homona \& Chrysanthou, 2012; Hajdin et al., 2018; Musa, Idris, Hashim, Othamn \& Kim, 2020). It is more effective to digitise intangible assets for the preservation of learning, animation, interactive performances, and other purposes compared to texts and 2D images and videos. Motion capture tends to provide a high degree of freedom in movement and high accuracy of metadata in capturing and recording movement and expression.

Research has been done throughout the continent, for example, digitising the Cypriot folk dance in Cyprus, preserving the ba jia jiang performance in Vietnam, and in Malaysia, there is research regarding preserving zapin dance, focusing on the usage of motion capture technology to gather valuable information and transform raw data into the $3 \mathrm{D}$ digital application in the form of gaming, video interactive, education entertainment, and learning animation as a platform of education and training as a preservation strategy. This provides more depth in a realistic, accurate, and new experience to the users in an all-around display of the performance characteristics in learning. 

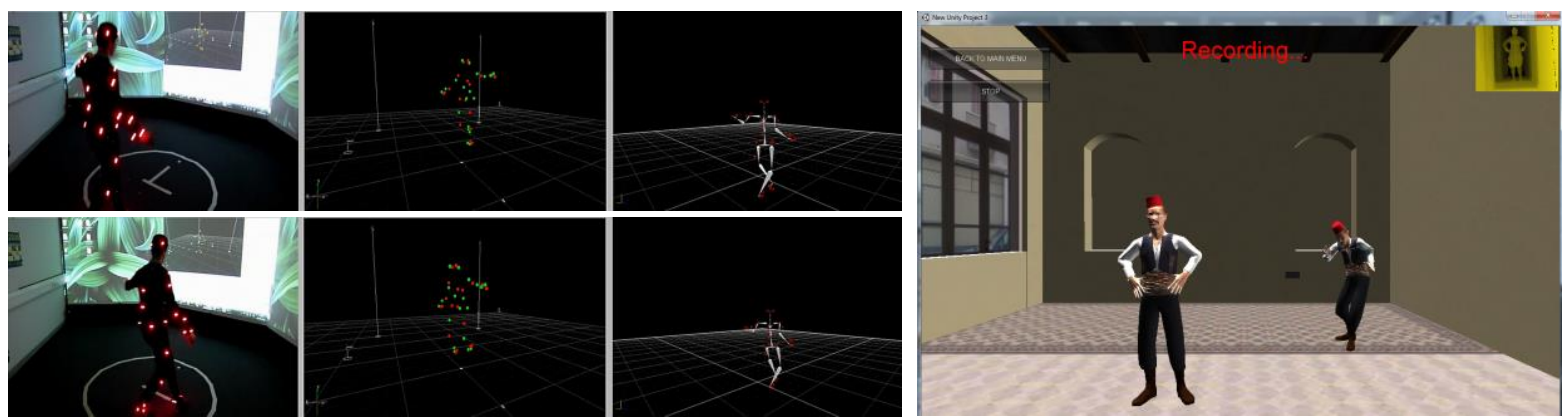

Figure 7: The Usage of Motion Capture Technology in Interactive Education Source: (Stavrakis et al., 2012)

On the other side of the coins, motion capture technology has the potential to be used as a tool to record qualities of trajectory images that might be used to generate significant human movements that are an objective representation of time and bodyline to establish movement's signature (Shan, Visentin \& Harnett, 2010; Azraai, Sabran \& Mat Jusoh, 2018). Activities, such as performing arts, are full of cultural myths that play a role in storytelling and give meaning to cultural customs to represent traditions as the in-depth value of the group heritage. Movement's signatures embody aesthetic qualities and in-depth values to the specific heritage that project meaningful denotation and connotation of the culture.
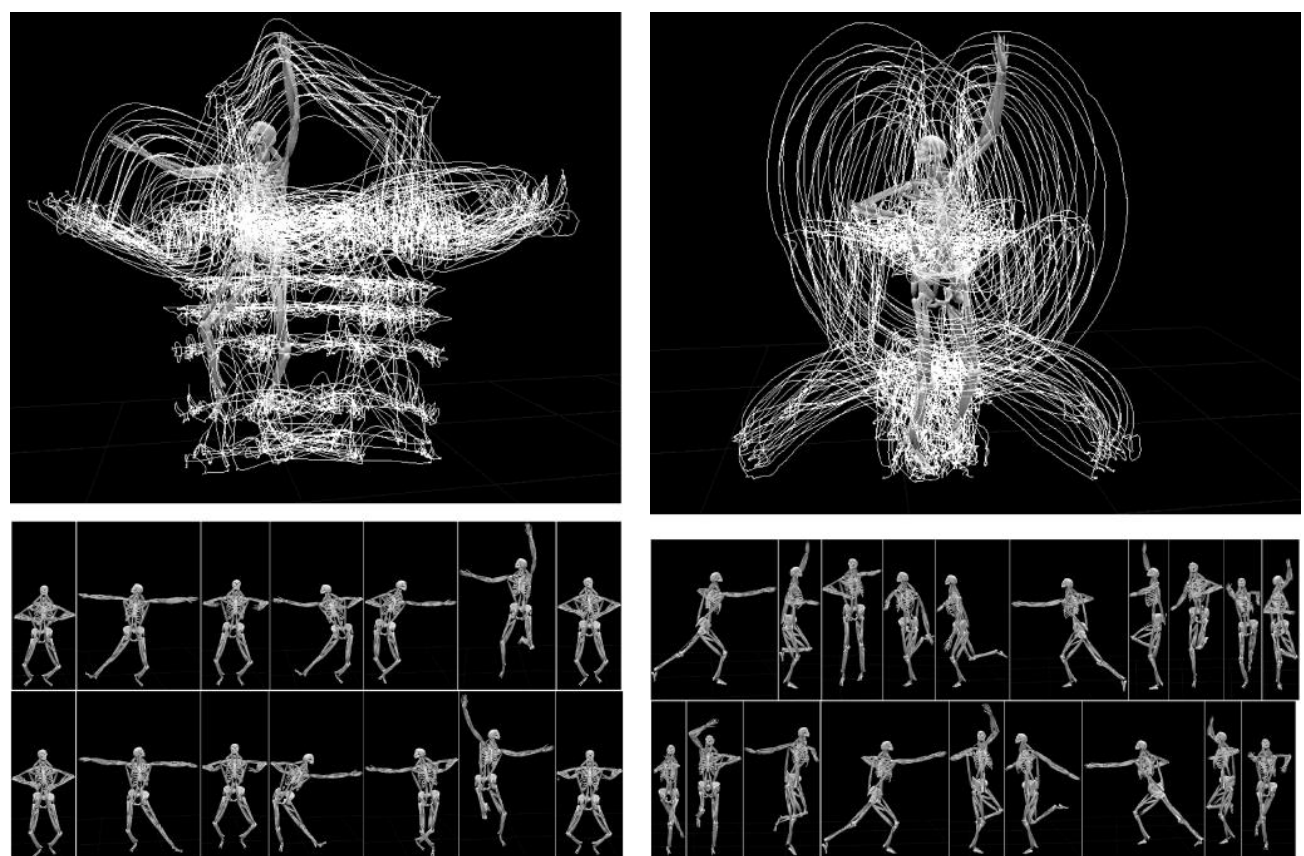

Figure 8: The Usage of Motion Capture Technology in Movement Signature Source: (Shan et al., 2010)

The usage of motion capture technology in performing arts can be used in sociology and anthropology to visualise the micro aesthetic movement that cannot be seen by naked eyes. The Malay folk dances are known as a culture full of myths and meaning. According to Md Nor (2011), the Malay folk dances involve secular and spiritual surroundings, alam. Alam acts as a 
Volume 4 Issue 15 (December 2021) PP. 01-13 DOI 10.35631/IJHAM.415001

teacher, source of artistic, creative, and aesthetic knowledge, and the paradigm in many Malay art forms including performing arts. In the dance, Alam offers stylistic knowledge that allows humans to replicate the imagery of flora and fauna. The Malay dance movement elements have a significant relation with Alam as the essence of aesthetic and inspiration. These motifs, imagery, and pattern are represented in symbols and abstracts that are beautifully choreographed and executed by emphasising the aspects of beauty, harmony, unity, and norms of the Malay culture, custom, ethics, and moral values.

\section{Discussion and Conclusion}

The use of motion capture technology in the digital preservation of intangible cultural heritage is often applied in a 3D application, such as entertainment, training, and gaming, and interactive education for education purposes. However, UNESCO indicates several measurements other than learning in digital preservation which can be applied towards cultural and heritage protection and preservation such as the enhancement of in-depth cultural values for human development and a holistic understanding. Therefore, the use of motion capture technology needs to be expanded in multiple purposes as a tool that can be extended into visualising micro aesthetic movements not visible through naked eyes in performing arts that can enhance cultural values and appreciation in the society.

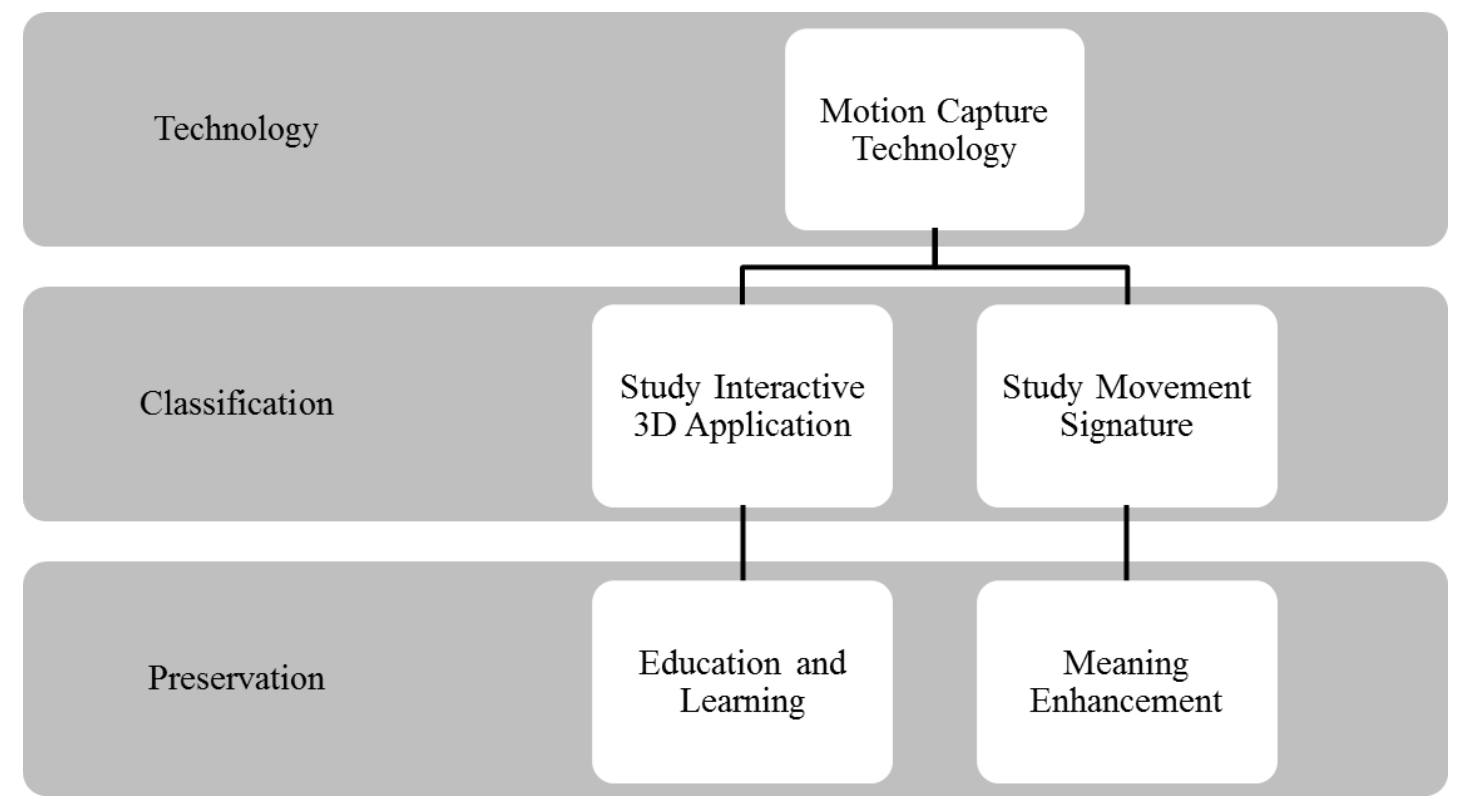

Figure 9: Functions of Motion Capture Technology in Digital Preservation

The research focused on exploring motion capture technology as a medium to discover a micro visual of joget dance movement and analyse the symbols or signs that can benefit and enhance cultural meaning holistically to the younger generation. It could also be used as a bridge in cross-cultural ideas to identify the root or origin of the culture that provides a local sense of unity and belongingness that can help develop a new interest and can expand in other fields of study. 
Volume 4 Issue 15 (December 2021) PP. 01-13 DOI 10.35631/IJHAM.415001

\section{References}

Ahmad, A. G. (2006). The cultural heritage of Southeast Asia: Preservation for World Recognition. Journal of Malaysian Town Plan, 3(1), 52-62.

Amin, R., Yatim, N. F., Deraman, A., \& Baker, O. F. (2011). Repository model for intangible heritage "the Malay scenario." International Journal on Advanced Science, Engineering and Information Technology, 1(2), 227.

Azraai, N. Z., Sabran, K., \& Mat Jusoh, C. (2018). The art of silat: Mapping the trajectory lines for hidden symbols. Advances in Social Science, Education and Humanities Research, 207(Reka), 372-374.

Bannerman, H. (2014). Is dance a language? Movement, meaning and communication. Dance Research, 32(1), 65-80.

Gusmail, S. (2017). Tari serampang dua belas di Sumatera Utara kajian estetika melalui pendekatan multikulturalisme. Jurnal Pengkajian dan Penciptaan Seni. 4(1), 95-104.

Hajdin, M., Kico, I., Dolezal, M., Chmelik, J., Doulamis, A., \& Liarokapis, F. (2018). Digitization and visualization of movements of Slovak folk dances. International Conference on Interactive Collaborative Learning, 21, 1964-1975.

Hang, P. W. (2020). Asal usul joget dan pantunnya dalam tamadun Melayu. Retrieved from https://www.thepatriots.asia/asal-usul-joget-dan-pantunnya-dalam-tamadun-melayu/

Idris, M. Z., Mustaffa, N., Othman, A. N., \& Abdullah, M. F. W. (2017). Exploring principle components for digital heritage preservation on Malay folk dances. International Journal of Academic Research in Business and Social Sciences, 7(10), 738-747.

Kabanda, P. (2014). The creative wealth of nations: How the performing arts can advance the development and human progress. World Bank Policy Research Working Paper, 7118.

Kico, I., Grammalidis, N., Christidis, Y., \& Liarokapis, F. (2018). Digitization and visualization of folk dances in cultural heritage: A Review. Inventions, 3(4).

Koff, S. (2012). Towards a definition of dance education. Childhood Education. 77(1), 27-32. M.Hum, M. T., \& Muhammad Dja'far, F. (2014). Ronggeng dan Serampang Dua Belas Dalam Kajian Ilmu-Ilmu Seni. Indonesia, Medan: USU Press.

Manaf, Z. A., \& Ismail, A. (2010). Malaysian cultural heritage at risk?: A case study of digitisation projects. Library Review. 59(2), 107-116.

Md Noor, S., Khor, Y., \& Mohamed, R. (2013). Potentials and challenges of involving indigenous communities in ecotourism in Belum-Temenggor Forest Complex, Perak, Malaysia. In B. Mohamed, \& A. Bahauddin (Eds.), Proceedings of International Conference on Tourism Development Building The Future Of Tourism (pp. 332-344). Penang, Malaysia.

Md Nor, M. A. (2011). Malay-Islamic zapin dance and soundscapes from the Straits of Malacca. Austronesian Soundscapes Performing Arts in Oceania and Southest Asia. Amsterdam University Press, 4, 71-84.

Muhamad, H. (2014). Folio tarian RIMUP. Retrieved from https://www.slideshare.net/hazizon/folio-tarian-rimup

Musa, N., Idris, M. Z., Hashim, M. E. A. H., Othman, A. N., \& Kim, L. C. (2020). Digital preservation for Malay folk dance expression: Developing a framework using motion capture, aesthetic experience and laban theory approach. Journal of Advanced Research in Dynamical and Control Systems. 12(1), 995-998.

Musiani, F., \& Schafer, V. (2017). Digital heritage and heritagization. Research in Social Sciences on the Internet. 
Volume 4 Issue 15 (December 2021) PP. 01-13 DOI 10.35631/IJHAM.415001

Ooi, M. (2011). Cultural dances and traditional musical instruments of Malaysia. Retrieved from https://tsnra.wordpress.com/2011/09/16/4-cultural-dances-of-malaysia/

Parani, J. (2018). Nusantara cultural interaction the case of joget as transborder entertainment. Paradigma Jurnal Kajian Budaya, 8(1), 1.

Rohidi, T. R. (2015). Pengkaryaan dalam bidang seni: Pembuktian intelektual dalam ramah akademik. International Conference Practice Based Research, 1-4.

Shan, G., Visentin, P., \& Harnett, T. (2010). A novel use of 3D motion capture: Creating conceptual links between technology and representation of human gesture in the visual arts. Leonardo, 43(1), 34-42.

Sheppard, M. (1972). Taman Indera: Malay decorative arts and pastimes. London, England: Oxford University Press.

Soon, L. W. (2017, May 7). Keeping alive a royal art form. The Star Online. Retrieved from http://www.thestar.com.my/news/education/2017/05/07/keeping-alive-a-royal-artform/

Stavrakis, E., Aristidou, A., Savva, M., Himona, S. L., \& Chrysanthou, Y. (2012). Digitization of Cypriot folk dances. Lecture Notes in Computer Science (Including Subseries Lecture Notes in Artificial Intelligence and Lecture Notes in Bioinformatics), 7616 LNCS, 404-413.

Syu, Y. S., Chen, L. O., \& Tu, Y. F. (2018). A case study of digital preservation of motion capture for Bā Jiā Jiāng performance, Taiwan religious performing arts. Lecture Notes in Computer Science (including subseries Lecture Notes in Artificial Intelligence and Lecture Notes in Bioinformatics), 11197 LNCS.

UNESCO. (2003). Convention for the safeguarding of the intangible cultural heritage. Retrieved from https://ich.unesco.org/en/convention

UNESCO. (2015). Operational guidelines for the implementation of the World Heritage Convention. Paris: UNESCO World Heritage Centre.

Wan Muhammad Fauzan, W. M. A., \& Said Husain, S. K. (2018). Geometri dalam tarian zapin. Asian Journal of Environment, History and Heritage, 2(2), 331-342.

Yayasan Warisan Johor. (2018). Tarian joget. Retrieved from http://www.ywj.gov.my/tarianjoget/ 